\title{
The Continuing Horror Story of Spiegelgrund: Mental Health, Compassion, Awareness and Incarceration Peter Collins
}

$\mathrm{B}$ etween the 1950s and the 1970s, Canada was secretly working with the CIA to facilitate and participate in psychiatric experimentation on Canadians (Collins, 1988). Along with the standardized sensory experiments, which included massive doses of LSD and other psychoactive drug cocktails, they were pushing and testing pain and sanity thresholds. This litany of horrors was perpetrated in the quest to develop and hone "tools" which could be used to extract information from Soviet spies (after all, we have to watch out for those damn communists ... oh sorry, it's the Muslims now, isn't it?). All that "experimentation" is now sadly paying dividends in Guantanamo Bay and other secret American-run torture prisons, all neatly tucked away from prying eyes (Klein, 2007).

When we look into Canada's not-so-distant past, the ripples in toxic pools of government sanctioned torture are still touching the shores. Experimentation on prisoners, the socially isolated, the mentally frail, using state certified lobotomies, electroshock, castration and sterilization - this is Canada's deplorable legacy. It would be dishonest to overlook the extensive commercial pharmaceutical experiments which were conducted without consent in Canadian prisons and psychiatric asylums where the prisoners were legally considered to be people without any rights. All of this torture was inexplicably carried out on the heels of World War II, after the Allies had "discovered" what had gone on behind the not-soclosed doors of the Nazi war machine with its many scientists and doctors performing large scale human experiments in support of their genocidal "final solution".

A side dish to the main course is Spiegelgrund, ${ }^{1}$ a clinic asylum in Vienna, Austria which performed grotesque experiments and "scientific" murders in the quest to "cleanse" the Arian race. Dr. Heinrich Gross of Spiegelgrund fame was complicit in thousands of murders and his signature appears on over 200 documents declaring children unfit to live during the Nazi Lebensunwertes Leben ${ }^{2}$ (Life Unworthy of Life programme) (Agamben, 1998). Dr. Gross, post WWII, became one of Austria's most respected neuro-psychologists and forensic experts, receiving many awards and accolades while working for the Austrian courts of law as a psychiatric expert until 1997. Dr. Gross kept body parts of children he murdered and continued to work on them in his archive at Spiegelgrund 
right into the late 1990's. Many of the murder victims were children of the so-called "socially undesirable" - the mentally ill, gypsies, gays, Jews, Blacks and criminals or anyone not "acceptably" Arian. Post-WWII, some of this gruesome collection was portioned and shared with research clinics around the world, so the violations continued after their deaths and after Europe's liberation.

The corrupting stench of complicity has wafted across oceans of water and time. The years have passed, memories have faded, revulsion replaced by apathetic complacency. Time marches on and the crushing black boots have been replaced by business suits in our age of distraction, Super Bowls, terrorism, World Cups, crime rates, celebrities, the Olympics, reality TV and fashion - a blended opiate-swill for the masses. All this glitter built on the backs of the disenfranchised, the dispossessed and poor, while multi-national conglomerates rape the earth, steal the future and hoard misappropriated wealth with governmental blessings. Wal-Mart sells us cheap televisions and front row seats, while CNN and the like deceive, distract and conceal with their repetitious, rapid-fire sound bite "news reports". Our complacency allows complicit governments to cut, tear and shred the environment and social safety nets while filling the coffers of the few and the rich.

With the hard winds of opportunity, greed and crisis blowing, many Canadian social programs have been cut and nowhere is this more evident than in the mental health facilities that have been closed by Conservative governments (in name and spirit). Individuals with mental health problems who run afoul of the Canadian State find themselves placed in prison instead of social and supportive mental health facilities. Seventy-five percent of Canadian youth prison / custody populations have a diagnosed mental disability (Howe and Covell, 2007, p. 168). Canada criminalizes mental disability and through this atrocity fails to protect the most vulnerable. Judge Irwin Lampert is quoted in the Moncton Times and in a court transcript on April 24, 2007 as saying:

Jails have become de facto mental institutions ... [G]overnment needs to put more resources in place so mentally ill people get the treatment they need and aren't left to be dealt with by the justice system. ${ }^{3}$

A glance backward provides some context. The British Parliament passed the "Confinement Act" in the early 1800s, an act that regularly consigned the mentally ill to life inside miserable prison asylum walls. In 1810, while working to document and validate "treatment" at the hospital of St. Mary of Bethlehem ("Bedlam Asylum") in London, William Black 
created a table (Black's List) of mental illnesses. While Black's list appears similar to the current psychiatric black book of authority The Diagnostic and Statistical Manual of Mental Disorders, we have not strayed very far from Bedlam. We have some meandering debates among our academics and complicit "correctional experts" have published papers documenting, commenting, and venturing down the road of examining for the purpose of validating the horrific practice of imprisoning those with mental disabilities (Hayes, 2005; Glaser and Florio, 2004; Jamieson et al, 2000). Our predisposition to shovel inconvenient members of the human family off behind closed doors is an enduring conduct that exposes the rot that eats away at our credibility and underlines human unkindness.

The current annual budget of the Correctional Service of Canada is close to $\$ 2$ billion, approximately $72 \%$ of which is allocated to "care and custody" expenses (Correctional Service Canada Review Panel, 2007). This figure is in addition to provincial correctional expenditures. Despite the continuing drop in crime rates, incarceration rates in Canada continue to increase, including incarceration rates for women (Canadian Association of Elizabeth Fry Societies, 2008). The current Canadian Conservative government intends to build regional super prisons while simultaneously lengthening sentences, increasing minimum sentencing and reducing parole. This government is constantly trying to pass repressive prison-oriented legislation clearly mistaking intelligent holistic responsive action to reduce the causes of crime with being "soft on crime". Under Conservative right wing ideology, the overall prison population and the costs to society will rise dramatically. Over the last 25 years, Canadian legislators have created some of the longest prison sentences in the world and Canada is no longer just flirting with the U.S. culture of incarceration. This enthusiasm for incarceration occurred before and during the patterned closures of many Canadian mental health facilities. ${ }^{4}$ Canada is also dealing with - or failing to deal with - an increasingly complex homelessness problem. The streets and prisons are now Canada's dumping ground for the mentally ill. As funding for mental health care has diminished the Canadian justice system continues to press the mentally ill into prisons. Indeed, the 2004 Report of the Office of the Correctional Investigator found that the percentage of federal prisoners with a diagnosed mental disorder rose 61 per cent between 1997 to 2004 (Office of the Correctional Investigator, 2005). Prisons have neither the facilities nor are they structured to improve, assist or deal with mental health issues. Prison guards simply do not have the skills, the training or the collective will to meaningfully deal with these issues.

A recent and particularly horrible example of Canadian prison injustice 
came into view on October 19, 2007, at 7 am, when the body of nineteen year old Ashley Smith was pulled from a segregation cell in Grand Valley Prison (GVI) in southern Ontario. GVI is a federal prison ironically built to replace Kingston's medieval Prison for Women (P4W), which was shut down under the weight of Madam Justice Louise Arbour's scathing commission ${ }^{5}$ into the brutalising conduct of male Correctional Services Canada (CSC) prison guards who had stripped and cut the clothes off a number of female prisoners while filming the procedure in front of other males. At fifteen years old, Ashley had been sentenced to youth detention (prison for children) for throwing crab apples at a postal worker. Under the crushing weight of imprisonment, Ashley was immersed into endless personal trauma and crisis, but received no meaningful assistance from Canada's federal prison service. Four years later, while on suicide watch Ashley died a lonely death in a bleak segregation cell. CSC will not divulge when Ashley was transferred from the children's prison system into adult prisons and there is no explanation as to why she was shipped so far from her home province of New Brunswick. What we do know is that while Ashley was being held at the Saskatchewan Regional Psychiatric "Treatment" Centre (RTC), she was assaulted by prison staff. A guard supervisor by the name of John Tarala was subsequently suspended, and formally charged with assault, though the charges were later dropped (Dalton, 2008). After the alarm that Ashley had been assaulted was raised, she was transferred to GVI prison and placed on a suicide watch, and it appears the guards actually watched, or walked away, while she died (see Ombudsman and Child and Youth Advocate, 2008; Office of the Correctional Investigator, 2008).

It is an undeniably dangerous venture to bring charges against a Canadian prison guard (in this case, John Tarala), no matter how abhorrent the guard's conduct. The guard's "brotherhood" protectively circles, are powerful, influential and remorseless in defence of each other. Regardless of their self-protection efforts, nine prison guards were suspended without pay following Ashley's death and two guards were charged with criminal negligence causing death. In November 2007, the Canadian Television Network (CTV) reported that prison guards had seen Ashley alive with a ligature around her neck and walked away. Clearly, Canadian prisons are not the soft places that guards, the media and political hacks claim. If you remain unconvinced just visit young Ashley's grave and ask her.

Notwithstanding the moral obscenity perpetrated in the name of justice when courts place the young and the mentally ill in prison settings, it seems clear that we all bear responsibility for the social and state mistreatment of the vulnerable, both pre- and post-imprisonment. It is far too late to 
say we did not know. If we did not, it is because we did not want to know. While there are too many shocking stories to share, I would like to share another situation that involves a prisoner who has mental developmental issues (and who is still alive) and how he was treated by many (guards and prisoners) in the prison in which I am currently incarcerated. I recognize, with deep sadness, this scenario is playing out every day in different Canadian prisons.

His name is W.W. and his conduct and crimes flow from inherited congenital mental defects that were exacerbated through traumatic childhood experiences in which he was the victim of sexual abuse from his primary caregiver - his father, who emotionally, physically and sexually abused him. Coupled with mental illness, his horrific childhood and the lack of community support, supervision and protection, he did what many victims of sexual abuse do, he passed it on, and it involved the most vulnerable - children. While everyone recoils in horror, it would serve us well to remember W.W. is damaged and the violations he experienced as a child, along with his social isolation, and psychological and physiological mental impediments contributed to his inappropriate conduct. We need to consider this child trapped in a man's body. I agree that children need to be protected from W.W., but W.W. apparently needs to be protected from us.

Context is required. If we do not look beyond the immediate circumstances of the offence and acknowledge the whole picture, who will? W.W. presents in the mental age range of 8 to 12 years old and is clearly operating with a diminished mental capacity. His general ability to understand social situations is skewed. He has personal boundary and "appropriateness" issues, which clearly contributed to his crimes and continues to drive a wedge between him and meaningful social contact. W.W.'s problems are further compounded by health and hygiene difficulties. Prison guards at Warkworth federal prison encouraged W.W.'s antics by "playfully" writing up charges and then laughing with each other as he would feign outrage and rip up the charge sheet. While amusing for the guards, it also provided W.W. interaction in a non-threatening environment. However, the interaction also reinforced socially unacceptable behaviour. Throwing fits was defused and funny at Warkworth, but after his transfer to Bath prison the guards say they interpreted his conduct as threatening and unpredictable. It seems that W.W. also learnt to mimic socially corrosive communication techniques from some of the prisoners and guards. When W.W. was not welcome or bothered someone he received rude and abrupt communication (e.g., "Get the fuck out here!" or "Beat it ya fucken goof!"). As eloquent as this appears on paper, in the prison context it is very offensive and can even 
result in the loss of life. W.W. would mimic this without understanding the potential dangers inherent in these prison warnings and challenges, and his uttering them should not be held against him. However, this concept may be difficult to grasp if the prisoner who was being spoken to in this manner has no comprehensive appreciation of W.W.'s limitations. In that situation there could be an abrupt and permanent end to W.W.'s story as non-response or turning the other cheek to a challenge in prison can result in an escalation of violence.

In W.W.'s continuing effort to be accepted he tries to shake everyone's hand, straining for acceptance and confirmation that he is safe. He talks endlessly and repetitively about anything, everything and nothing. His effort to receive a human connection is something many of us experience daily and take for granted. Trapped in prison with a sentence that he does not fully understand, he lives in perpetual loneliness and fear. No peer, no equal, no friend. He seeks acceptance from most everyone, regardless of how barren and insincere it may be when it is offered. At best, he is patronized, at worst, ridiculed, harassed and dogged with hostility. Instead of human kindness, W.W. finds himself ignored - a common human response to situations that make us uncomfortable. While there are generally accepted (if somewhat limited) methods of evaluating someone's intelligence and emotional quotient, this did not prevent W.W. from being sent to prison. Clearly his IQ and EQ are of a diminished capacity. On the other hand, those who knowingly treated him so poorly obviously suffer emotional hindrances which prevent them from finding the required empathy, kindness, compassion, and understanding to be gentle with someone so frail and vulnerable. I have no doubt that those who conducted themselves in either fashion continue to have many justifications and explanations.

The all too predictable result of hostilities directed at W.W. was that he sought (seeks) refuge with prison guards which then resulted in accusations from and against some prisoners (correctly or not). The guards would then threaten blanket sanctions against all the prisoners (guilty or not). Then the guards would simply return to whatever it is they do in their concrete towers, blissfully unaware that they have only aggravated the problem. As all of these various issues were bubbling to the forefront of prison life, guards and prison administrators had begun to complain that W.W. was "too much" to manage in Bath prison (we tried nothing and that didn't work!?).

With the piety that accompanies the oblivious, misguided and opportunistic, the label of informant was hung on W.W. and this served the dual purpose of validating their anger and justifying the further 
ostracization of this mentally limited, vulnerable and socially alienated individual. In reinforcing circles some prisoners were telling each other or anyone who would listen that "he's not really that mentally retarded". They would argue that he is dirty and does not shower, but they never consider he is afraid to go to the shower because of hostility in the prison and due to his history of abuse. Several of the very same prisoners who would call W.W. an informant stand with guards discussing all manner of issues. Over the years, the one truth I have noticed is that, almost invariably, those loudly labelling others as informers do so to conceal or distract attention from their own informing conduct. I have heard how reviled our self-appointed "social champions" are by W.W.'s crime. I notice, however, that they do not harass, belittle or intimidate other people with similar convictions at this prison and the only difference I can see is that those individuals are not as weak, alone or vulnerable and therefore may be more capable of defending themselves.

W.W. experienced many additional difficulties from being exposed to prison environments, guards and some of the prisoners. While many prisoners and guards for that matter, have empathy and compassion when it comes to the unrelenting limitations of someone with developmental hindrances, this is not always the case. Short of being removed from a prison environment altogether, what W.W. needed was to live in one of Bath Prison's self contained 10 men units and not be exposed to the traditional prison range environment. In the 10 man living units there are private showers and food preparation areas, which would have resulted in W.W. being able to go to the bathroom and shower behind a locked door and thereby without being fearful. It would have meant that W.W. would not have had to go to the main prison Kitchen food service area which feeds a couple of hundred men. The result of this would have reduced the contact W.W. had with those prisoners who are currently incapable of the required maturity, insight and kindness.

As the Peer Health Counsellor and a concerned person, I proposed that W.W.'s problems could be resolved by moving him to a 10 man unit with several more mature, ethical, and concerned prisoners trained to assist him by providing support and structure while helping to undo some of the reinforced negative behaviours that he had learnt in prison, to help him develop useful life skills in a predictable and friendly environment. Bath authorities did not accept the housing alternative. The Prisoner's Committee advised me the Warden decided W.W. needed more supervision than was available in the housing units and left him on the prison range. It is my opinion, however, that the supervision pretence was just a thoughtless, convenient and callous excuse to avoid making 
the effort to address the problem in a meaningful way. A "correctional illusion" that exists in the prison context is that a guard capable of looking down a prison range from a security bubble provides supervision. In this context, it is a diversionary red herring. Guards may watch, but this provides no support for someone like W.W. - for instance, no one looking from the security bubble can see in a cell, the laundry room or the washroom. No guard, for example, saw someone pour water into and subsequently ruin W.W.'s television, a television that would have taken W.W. well over a year to purchase because he spent most of his limited income on cigarettes.

At any rate, my suggestions were not acted on and the "status quo" resulted in the Bath administration eventually finding enough excuses to state they were unable to deal with W.W.'s problems and "Emergency Transferred" him into solitary confinement in Millhaven Maximum security prison.

I cannot imagine any more vulnerable individuals than Ashley due to her youth, distance from home, lack of support and obvious emotional stress, and W.W. because of his mental frailty, his physical weakness and the lack of support or friendship. Incapable of defending themselves they were chained and forced into places you would be terrified to enter. Now Ashley is dead and W.W. is held in isolation at Millhaven prison. I fear he is destined for Ontario's Regional Psychiatric Treatment Center - an even harsher prison.

That we should care so little, as a society, about the impact and outcomes of our approach to mental health services and the way we treat people with mental health disabilities is a shame. That we treat children and young people with disabilities with the same lack of concern is doubly shameful. ${ }^{6}$

These prison horrors exist and operate in your name, funded with your taxes. You have the right and frankly, the obligation to speak up.

The measure of any human being, organization or country can be estimated by what they are capable of doing and what they actually do. Shame on Canada for placing the young and the mentally disabled in prisons. If after reading this you do not write to your Member of Parliament and complain, shame on you.

Say nothing, and you are the problem at the lower end of the Spiegelgrund spectrum. 


\section{ENDNOTES}

1 Spiegelgrund (1999 Documentary) by Angelika Schuster, Tristan Sindelgruber and BBC News (Europe) Tuesday, March 21, 2000 \& Sunday, April 21, 2002.

2 Hitler's "euthanasia programme".

3 Judge Irwin Lampert as quoted in the Moncton Times and Transcript on April 24, 2007.

4 In no way does this author endorse the use of psychiatric asylum prisons. However, I note that effective and properly staffed facilities which are geared to assist people get on their feet and develop the ability to function with whatever support is required to assist them in such socially oriented endeavours that provide mechanisms toward independent living has to be better than placing the intellectually challenged and / or damaged, along with those dealing with mental disabilities in prisons under which conditions they will suffer endless abuses or worse by prison administrations that are incapable of dealing with complex issues without resorting to force and punishment (not to mention the predatory behaviours of some of the other prisoners).

5 See the Report of the Commission of Inquiry Into Certain Events at the Prison for Women in Kingston (1996), a.k.a. "The Arbour Commission".

6 Connecting the Dots: A report on the condition of youth-at-risk and youth with very complex needs in New Brunswick. New Brunswick Ombudsman and Child Youth Advocate (Mr. Bernard Richard), January 2008, p. 52.

\section{REFERENCES}

Agamben, Giorgio (1998) Homo Sacer: Sovereign Power and Bare Life, Stanford: Stanford University Press.

Collins, Anne (1988) In the Sleep Room: The Story of the CIA Brainwashing Experiments in Canada, Toronto: Lester \& Orpen Dennys.

Commission of Inquiry Into Certain Events at the Prison for Women in Kingston (1996) Report of the Commission of Inquiry Into Certain Events at the Prison for Women in Kingston, Ottawa: Public Works and Government Services Canada.

Correctional Service Canada Review Panel (2007) A Roadmap to Strengthening Public Safety: Report of the Correctional Service of Canada Review Panel, October, Ottawa: Minister of Public Works and Government Services Canada.

Dalton, Melinda (2008) "Charges Dropped Against Jail-Death Guards: Two Local Men, Two Others Fired after Suicide", The Hamilton Spectator - December 8, retrieved from http://www.thespec.com/News/BreakingNews/article/478860

Canadian Association of Elizabeth Fry Societies (2008) Fact Sheet: Criminalized \& Imprisoned Women, retrieved from http://www.elizabethfry.ca/eweek08/pdf/ crmwomen.pdf

Glaser, William and Florio, D (2004) "Beyond Specialist Programmes: A Study of the Needs of Offenders with Intellectual Disability Requiring Psychiatric Attention", Journal of Intellectual Disability Research, 48(6): 591-602.

Hayes, Susan (2005) "Prison Services and Offenders with Intellectual Disability: The Current State of Knowledge and Future Directions", paper presented at the 
$4^{\text {th }}$ International Conference on the Care and Treatment of Offenders with a Learning Disability - 6-8 April, retrieved from www.ldoffenders.co.uk/conferences/ 4thCon2005/4thConFiles/Prison ServicesSusanHayes.doc

Howe, Brian, and Covell, Katherine (ed's.) (2007). A Question of Commitment: Children's Rights in Canada, Waterloo: Wilfred Laurier University Press.

Jamieson, Elizabeth, Martin Butwell, Pamela Taylor and Morven Leese (2000) “Trends in special (high-security) hospitals 1: Referrals and Admissions", British Journal of Psychiatry, 176(3): 253-259.

Klein, Naomi (2007) The Shock Doctrine: The Rise of Disaster Capitalism, Toronto: Knopf Canada.

Ombudsman and Child and Youth Advocate (2008) Ashley Smith: A Report of the New Brunswick Ombudsman and Child and Youth Advocate on the Services Provided to a Youth Involved in the Youth Criminal Justice System, June, Fredericton: Office of the Ombudsman \& Child and Youth Advocate.

Office of the Correctional Investigator (2008) "Correctional Investigator Submits Final Report to Minister Stockwell Day on Death of Ms. Ashley Smith at Grand Valley Institution, Kitchener", Office of the Correctional Investigator, June 24, retrieved from http://www.oci-bec.gc.ca/comm/press/press20080624-eng.aspx.

Office of the Correctional Investigator (2005) "Report Highlights Dramatic Increase in Numbers of Inmates Mentally Ill: Implementation of National Strategy Urged to Address Crisis", Office of the Correctional Investigator - November 4, retrieved from http://www.oci-bec.gc.ca/comm/press/press20051104-eng.aspx.

\section{About the Author}

Serving a life sentence in prison, Peter Collins knew he had to come to terms with the consequences of his actions and so dedicated himself to working for positive social change. Since the late 1980s, when the official position of the Correctional Service of Canada was that intravenous drug use, tattooing, and sex were illegal - therefore not happening - until today when prisoners continue to be denied access to clean needles and syringes, Peter's tireless efforts to defend the health and human rights of prisoners have often led to strained relationships with prison officials, undermining his efforts to get paroled. While in prison, Peter earned an honours diploma in Graphic and Commercial Fine Arts, as well as a certification as a Frontier College ESL tutor. He is an Alternatives to Violence Project facilitator and Peer Education Counsellor. Peter was instrumental in setting up a Peer Education Office in his prison and has advocated on behalf of fellow prisoners on issues ranging from health access to employment. Regularly donating his time, expertise, and artwork to numerous charities and social justice initiatives, Peter's dedication has contributed to improved health and safety in the prison system, and by extension, in the community at large. 